\title{
THE TECHNO-ECONOMIC JUSTIFICATION FOR THE CHANGING OF A SYSTEM FOR SEPARATE HEATING/COOLING AND ELECTRICAL ENERGY PRODUCTION WITH A CCHP SYSTEM WITH A MICRO-TURBINE AND ABSORPTION REFRIGERATION UNIT
}

\author{
Ivica Glavan, Zmagoslav Prelec, Branimir Pavković
}

Original scientific paper

The system of separate production of heat energy from a boiler and cooling energy from a compression refrigeration unit powered with electrical energy from an external network can be replaced with a CCHP system based on the operation of a gas turbine and absorption refrigeration unit. For this purpose, models of the system were derived through the use of the object-oriented programming language Modelica, on the basis of which steady-state simulations were carried out, as well as technical-economic and the sensitivity analysis of the system, in relation to the changes of influential parameters such as coefficient of performance, the boiler efficiency, the ratio of the electric load, costs of electrical energy, fuel prices and investment costs. Developed system model is intended to be used in further research for dynamic simulations with implemented dynamic boundary conditions.

Keywords: absorption refrigeration unit; CCHP; compression refrigeration unit; micro-turbine; Modelica; sensitivity analysis; SimulationX

Tehno-ekonomska opravdanost zamjene sustava odvojene proizvodnje toplinske/rashladne i električne energije CCHP sustavom s mikroturbinom i apsorpcijskim rashladnim uređajem

Izvorni znanstveni članak Sustav odvojene proizvodnje toplinske energije iz kotla, energije za hlađenje iz kompresijskoga rashladnog uređaja i električne energije iz vanjske mreže može se zamijeniti CCHP sustavom koji se temelji na radu plinske turbine i apsorpcijskoga rashladnog uređaja. Za tu su namjenu napravljeni su modeli sustava primjenom objektno orijentiranog programskoga jezika Modelica, na temelju kojih su vršene simulacije za stacionarna stanja i izvedena tehnoekonomska analiza te analiza osjetljivosti sustava u ovisnosti o promjeni parametara kao što je faktor hlađenja, stupanj iskoristivosti kotla, omjer električnog opterećenja, cijena električne energije, cijena goriva i trošak investicije. Razvijeni model sustava koristiti će se u istraživanjima koja slijede za dinamičke simulacije s uvedenim dinamičkim rubnim uvjetima.

Ključne riječi: analiza osjetljivosti; apsorpcijski rashladni uređaj; CCHP; kompresijski rashladni uređaj; mikroturbina; Modelica; SimulationX

\section{Introduction}

The production of thermal energy $Q_{h}$ for heating requirements, which is obtained from a boiler (B) powered by fuel oil, and the cooling energy $Q_{c}$ from the compression refrigeration unit (CRU), powered by electrical energy from the external electrical network, represents a permanent expense during the operation of a heating, ventilating and air-conditioning (HVAC) system. Such a system could be improved by replacing the inefficient components of the system with those of higher efficiency. Another method of improvement can be achieved by replacing the base system with a new system that produces electrical, heat, and cooling energy, so called the CCHP system (Combined Cooling, Heating and Power). This system can be designed as a combination of the gas turbine powered generator and the absorption refrigeration unit (ARU). The replacement system should result in more favourable technical and economic parameters that would enable a return on the investment, and the creation of conditions for the income increase.

The functioning principles and the various energy analyses of the CCHP system, described in the literature $[1 \div 11]$, confirm that the CCHP system is applicable for HVAC applications of facilities.

This paper deals with the issue of the functioning of the CCHP system that takes place in a period of lower (LT) and higher tariffs (HT) of electric energy prices [12], either sold $C_{e, s}$, or bought from an external network $C_{e, p}$ [13]. Different natural gas cost $C_{f, N G}$ [14] and heating oil cost $C_{f, H O}$ [15] affect the economic feasibility of investing in the project. The best way to determine the feasibility of the investment is a techno-economic analysis, as well as a sensitivity analysis. The sensitivity analysis is a method used to assess the potential risks affecting the technoeconomic feasibility of investing in a project, where it is not only important to quantify the risk, but also to identify the factors to whose changes the project is particularly sensitive. In this paper, special attention was paid to the sensitivity analysis of a low-power CCHP system (up to 1 MW) [16], by using the programming language Modelica $[17 \div 19]$ and simulation environment Simulation X [20].

\section{The main components of the CCHP system}

The performance of a low-power gas turbine, the socalled micro-turbines is based on the Joule-Brayton process, where the gas temperature at the turbine inlet is limited to $950{ }^{\circ} \mathrm{C}$ in order to allow for the use of relatively inexpensive materials. The output gases temperature ranges from 200 to $300{ }^{\circ} \mathrm{C}$ [21]. Currently the market offers micro-turbines until $250 \mathrm{~kW}[22,23]$. Models with higher power can be designed as a combination of multiple smaller devices. The advantage of connecting more turbines (Fig. 1 and Fig. 2) is reflected in a higher efficiency with various loads, while the shortage is an increase in investment costs.

This paper discusses a CCHP system with microturbines with an installed capacity of $600 \mathrm{~kW}$, obtained by connecting three $200 \mathrm{~kW}$ micro-turbines [23].

The characteristics of the gas turbines from different manufacturers are based on the ISO standard conditions corresponding to the inlet air temperature of $15{ }^{\circ} \mathrm{C}$. Gas turbines, at different locations, operate in different 
environmental conditions which significantly affects the turbine's power and the specific fuel consumption [24].

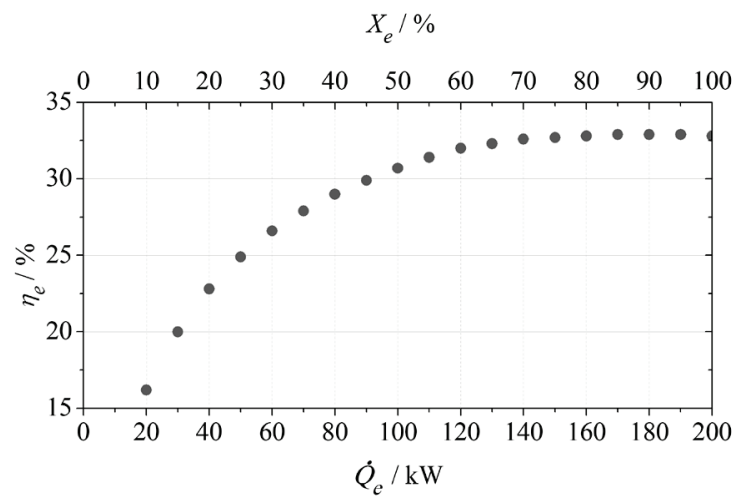

Figure 1 The efficiency of a low-power gas turbine, example: $200 \mathrm{~kW}$ turbine [23]

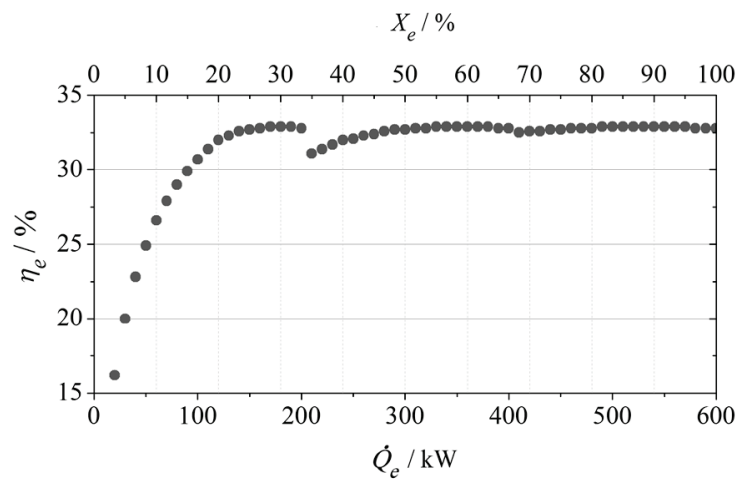

Figure 2 The efficiency of a low-power gas turbine, example: $600 \mathrm{~kW}$ turbine set consisted out of three $200 \mathrm{~kW}$ turbines [23]

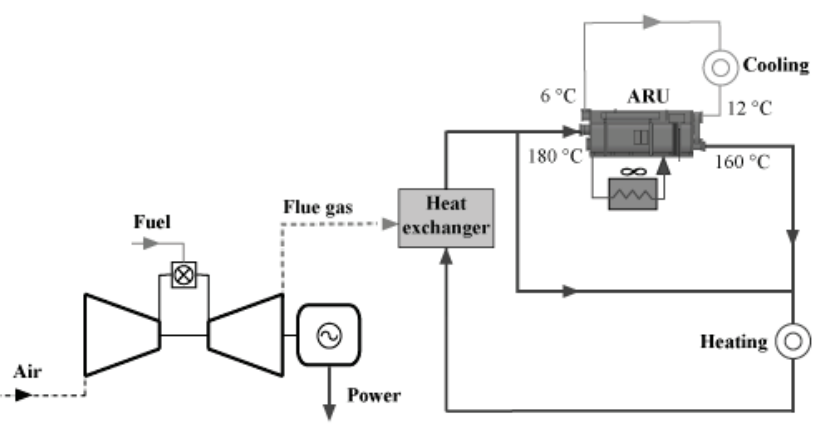

Figure 3 Tri-generational system, GT-ARU

CCHP system, shown in Fig. 3, provides the heat from the gas turbine, through the flue gases, and it is delivered to consumers for heating directly or for cooling by the operation of the absorption refrigeration unit. Depending on the needs of the consumers, the medium used for the heat transfer can be hot water, steam or flue gases.

The absorption refrigeration units (ARU) that work with binary mixtures $\mathrm{NH}_{3}-\mathrm{H}_{2} \mathrm{O}$ or $\mathrm{LiBr}-\mathrm{H}_{2} \mathrm{O}$, depending on the chosen mixture and number of degrees of absorption, require different temperatures in the heat generator of the device, and are distinguished by:

- Single-stage $\mathrm{LiBr}-\mathrm{H}_{2} \mathrm{O}$ unit, which operates with normal operating temperatures in the generator ranging from 60 to $110^{\circ} \mathrm{C}$, can be powered by warm water, hot water, low-pressure steam or directly by flue gas. The thermal/cooling ratio or coefficient of performance (COP) of such a device is in the range of 0,6 to 0,8 .

- Two-stage $\mathrm{LiBr}-\mathrm{H}_{2} \mathrm{O}$ unit, which operates with normal operating temperatures in the generator ranging from 120 to $170{ }^{\circ} \mathrm{C}$, can be powered by hot liquid, steam $(2 \div 8$ bar), or directly by flue gases. The thermal/cooling ratio (COP) of such a device is larger and ranges from 1,0 to 1,5 .

Regarding to the temperatures of flue gas output, the gas turbine systems can operate with single-stage or twostage absorption refrigeration units.

Since the two-stage refrigeration units operate with a higher COP, this research used a two-stage ARU with the installed cooling power of $872 \mathrm{~kW}$ selected from the catalogue of one of the producers [25]. The principle of the two-stage ARU is based on the same principles of thermo-chemical reaction of sorption and desorption as well as single-ARU. The difference is that the functioning of the two-stage ARU requires higher operating temperature, resulting in a higher $\mathrm{COP}$.

\section{System models}

This paper analyses gas turbines of installed capacity from 0,2 to $1 \mathrm{MW}$. This power scale is adequate to the small-scale power of the CCHP. In order to analyse the CCHP systems the energy models of the system are defined. The fuel energy $Q_{f}$ is transformed into various forms of energy such as heat $Q_{h}$, electrical energy $Q_{e}$ and cooling energy $Q_{c}$. The following models of thermotechnical systems were formed:
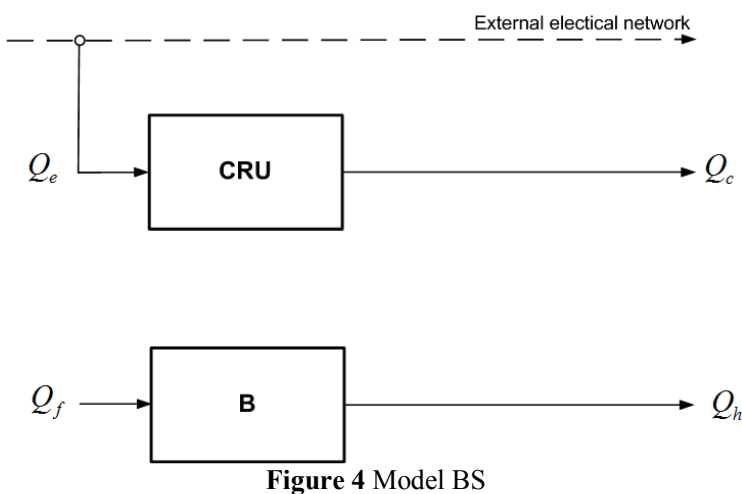

$Q_{e}$

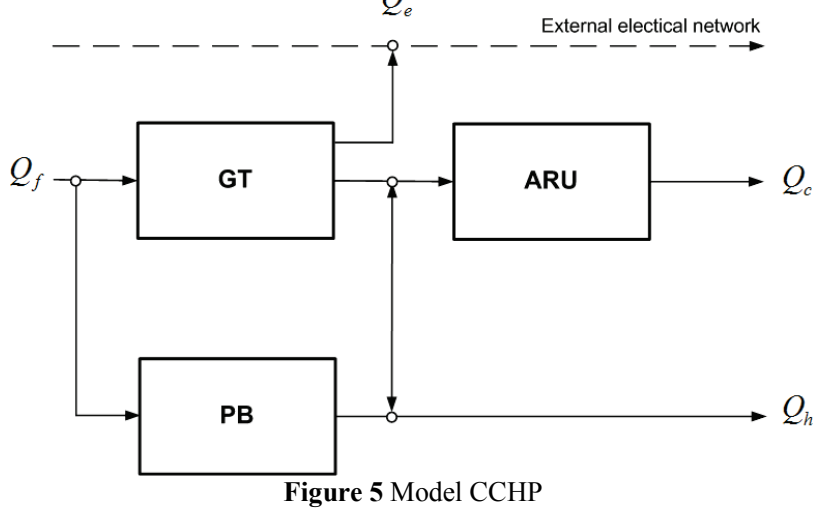

The basic model of the system (BS) is shown in Fig. 4. It includes the production of thermal energy from the 
boiler (B). The energy needed for cooling $Q_{c}$, is obtained from the compression refrigeration unit (CRU), powered by electrical energy obtained from the external network, while the demand for electrical energy is met through the external network.

The CCHP model, shown in Fig. 5, involves the production of electrical energy $Q_{e}$ by gas turbine (GT). The energy needed for the cooling $Q_{c}$ is obtained from the absorption refrigeration unit (ARU) using the output heat from the gas turbine. A peak boiler (PB) is used in order to compensate a possible lack of thermal energy.

\section{The techno-economic parameters of systems}

The basic characteristics by which we can analyse and compare the energy efficiency of the BS and CCHP systems are defined by Eqs. (1) $\div$ (18).

The electrical degree of fuel energy conversion of the gas turbine represents the ratio of generated electrical power and consumed fuel power by the gas turbine:

$\eta_{e}=\frac{\dot{Q}_{e}}{\dot{Q}_{f}}$

The consumption of fuel energy per unit of electrical energy of the gas turbine HR (Heat Rate):

$H R=\frac{1}{\eta_{e}}$

The ratio of the electrical load $X_{e}$ is the ratio of produced electrical power and the maximum electrical power of the gas turbine:

$$
X_{e}=\frac{\dot{Q}_{e}}{\dot{Q}_{e, \max }} \text {. }
$$

The ratio of thermal loads $X_{h}$ is the ratio of produced thermal power and the maximum thermal power of the gas turbine:

$$
X_{h}=\frac{\dot{Q}_{h}}{\dot{Q}_{h, \max }} \text {. }
$$

The ratio of the refrigeration load $X_{c}$ is the ratio of the cooling power and the maximum cooling capacity of the refrigeration unit:

$$
X_{c}=\frac{\dot{Q}_{c}}{\dot{Q}_{c, \max }} .
$$

The total level of the fuel energy efficiency:

$$
\eta_{t o t}=\frac{Q_{e}+Q_{h}}{Q_{f}} .
$$

The total energy efficiency of the BS model [26]:

$$
\eta_{t o t, B S}=\frac{Q_{e, C R U}+Q_{h, B}}{\frac{Q_{e, C R U}}{\eta_{e, a}}+\frac{Q_{h, B}}{\eta_{B}}}
$$

where is $\eta_{e, a}$, average efficiency ratio between the gross production of electrical energy and the consumption of primary energy for its production, and it is calculated as the average value for the entire European Union based on the Eurostat data. The values $\eta_{e, a}$ depend on the production and type of fuel. The share of electrical energy consumed in the Republic of Croatia is derived from various sources, where $50 \%$ of the necessary energy is imported [14] and whose sources depend on the country from which imports occur, which in turn affects the value $\eta_{e, a}$.

The total energy efficiency of the CCHP model:

$\eta_{t o t, C C H P}=\frac{Q_{e, G T}+Q_{h, G T}+Q_{h, P B}}{Q_{f, G T}+Q_{f, P B}}$.

On the basis of the information provided by the equipment manufacturer [23, 25, 27] functional correlation curves were made indicating individual characteristic values in dependence on the ratio of the load $\left(X_{e}, X_{h}, X_{c}\right)$ and the ambient temperature $T_{a}$, which enables the construction of a system model made up of sub-models: the gas turbine (GT), the absorption refrigeration unit (ARU), the boiler (B) and peak the boiler (PB) for covering peak thermal load.

The paper uses the functions of the characteristics of gas turbines $f\left(X_{e}, T_{a}\right)$ depending on the load ratio $X_{e}$ and the ambient temperatures $T_{a}$ for the location of Zadar [28] with a nominal power of $600 \mathrm{~kW}$ [23], where the function $f$ represents the characteristics of the gas turbine $\dot{Q}_{e}, \dot{Q}_{h}, \dot{Q}_{f}$ and $H R$.

The effectiveness of ARU is defined by the coefficient of performance according to the expression:

$C O P_{A R U}=\frac{\dot{Q}_{c}}{\dot{Q}_{h}}$,

where the cooling power is $\dot{Q}_{c}$, and the thermal power delivered to the heat generator of the absorption refrigeration unit is $\dot{Q}_{h}$.

The efficiency of the CRU is defined through:

$C O P_{C R U}=\frac{\dot{Q}_{c}}{\dot{Q}_{e}}$,

where the cooling power is $\dot{Q}_{c}$ and the electrical energy needed to operate the compression refrigeration unit is $Q_{e}$. The paper uses the characteristics of the refrigeration unit $\operatorname{COP}\left(X_{c}, T_{a}\right)$ in dependence of the load ratio $X_{c}$ and the ambient temperature $T_{a}$ [29].

The efficiency of the boiler is defined by: 
$\eta_{B}=\frac{\dot{Q}_{h}}{\dot{Q}_{f}}$

where $\dot{Q}_{h}$ is the produced heat power and $\dot{Q}_{f}$ is the spent fuel power. The paper uses the characteristics of the boiler $\eta_{B}\left(X_{t}, T_{a}\right)$ in dependence of the load ratio $X_{t}$ and the ambient temperature $T_{a}$ [27].

The expense of fuel for the gas turbine in a time period from $t_{0}$ to $t_{1}$ is as follows:

$E_{f, G T}=C_{f} \int_{t_{0}}^{t_{1}} \dot{m}_{f, G T} \mathrm{~d} t$,

where the price of fuel is $C_{f}, € / \mathrm{kg}$. The flow of the fuel for the gas turbine $\dot{m}_{f, G T}, \mathrm{~kg} / \mathrm{s}$, is calculated by:

$\dot{m}_{f, G T}=\frac{H R\left(X_{e}, T_{a}\right) \cdot \dot{Q}_{e}\left(X_{e}, T_{a}\right)}{3600 \cdot L H V}$,

where $L H V, \mathrm{~kJ} / \mathrm{kg}$ is the lower heating value.

The expense of electrical energy for the $C R U$ in a continuous time period from $t_{0}$ to $t_{1}$ is as follows:

$E_{e, C R U}=C_{e} \int_{t_{0}}^{t_{1}} \frac{\dot{Q}_{c}}{C O P_{C R U}} \mathrm{~d} t$.

The total expense of investment and maintenance $E_{t o t}$, $€$, is the sum of the cost of investment and maintenance. These costs are calculated based on the equipment unit price and installation, $C_{G T}, C_{A R U}, C_{P B}, € / \mathrm{kW}$, and the cost of operation and maintenance $C_{O \& M}, € /(\mathrm{kW} \cdot \mathrm{h})$ [30].The total cost of investment and maintenance is calculated according to:

$E_{t o t}=E_{G T}+E_{A R U}+E_{B}+E_{O \& M}$.

The income in a CCHP model is based on the profits acquired from the sale of electrical energy $I_{e}$, that is:

$I_{e, s}=Q_{e} \cdot C_{e, s}$

where $C_{e, s}, € /(\mathrm{kW} \cdot \mathrm{h})$, is the selling price of electrical energy depending on the tariff system.

Profit $(P)$, which is realized through a CCHP model, is the difference between the expense $(E)$ of the basic model and the CCHP model decreased with the income of the CCHP model. The income $(I)$ achieved through a CCHP model is the income earned from the sale of electricity to external network and the income achieved from greenhouse gas emission costs. The expense $(E)$ of the CCHP models is the fuel expense $E_{f}$.

The profit of the CCHP system is as follows:

$$
\begin{aligned}
P_{t o t}= & \left(E_{f, B S}+E_{e, p, B S}\right)- \\
& \left(E_{f, C C H P}-I_{e, s, C C H P}-I_{G H G, C C H P}\right) .
\end{aligned}
$$

In the paper the achievable income of the greenhouse gas emission costs is neglected due to a low cost price of the income paid from greenhouse gas emission cost in the area of the Republic of Croatia [31].

The payback period with the CCHP model represents the ratio of investment costs in relation to the annual profit, and it amounts to:

$$
P B P=\frac{E_{t o t}}{P_{t o t}} .
$$

\section{Energy system analysis}

The input values of heating and cooling load (external load), in case of replacing the system of separate production, can be collected after years of the operation, on a daily or hourly level or calculated and displayed as an average of the daily or monthly load values.

For the purposes of the dynamic simulation, whose load values change on an hourly basis during the year it is necessary to have available an application that is able to implement a dynamic simulation for such a time step, while for the purposes of the simulation with higher time step (a month) it is possible to work with applications that are based on the table calculator such as RetScreen [32] and other similar solutions.

During the simulation based on the input load, parameters are being calculated for the individual system components that are defined by static, $y=f(x)$ or dynamic characteristics, $y(t)=f[y(t)]$.

In the case of a simulation, with a time step lower than $1 \mathrm{~h}$, and defined static / dynamic characteristics of the system commercial applications with a closed program code such as TRNSYS [33] can be used, or an individual program solution can be created by using programming languages such as Modelica [17 $\div$ 19]. Modelica is an object-oriented language for describing physical models and their components, suitable for describing complex physical systems from areas such as mechanical, electrical, electronic, hydraulic, and thermal engineering.

In this paper, describing a particular example, the average values of the input loads were used as inputs in the individual software solution for the CCHP mo made in the programming language Modelica and simulation environment SimulationX [20], while components are described by static characteristics as well (Fig. 6, Fig. 7).

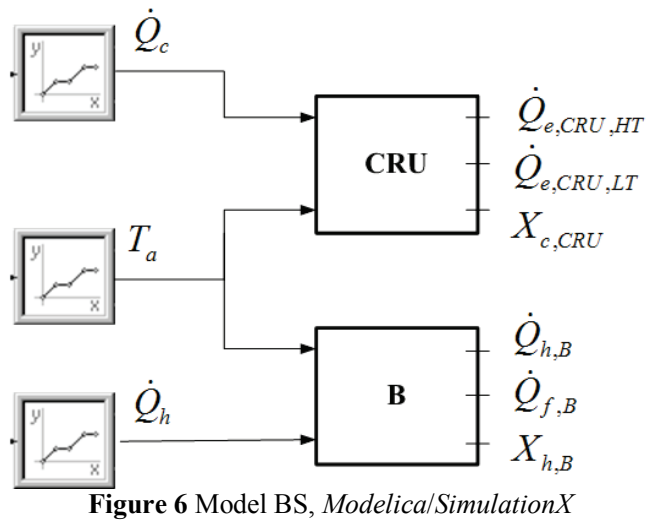




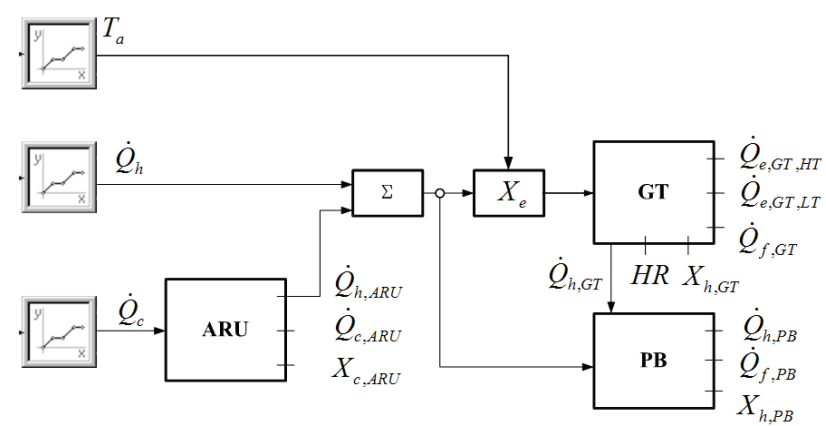

Figure 7 Model CCHP, Modelica/SimulationX

This analysis uses the input value of the average daily load that can be treated as a measured or calculated value using RetScreen [27] for the supposed location of Zadar city (Croatia), the space size of $20000 \mathrm{~m}^{2}$ and the losses/gains of heat from $70 / 40 \mathrm{~W} / \mathrm{m}^{2}$. Considering that Reetscreen does not offer the calculation of external load on the hour/day level the resulting values of load on the month level are brought to daily level and divided on the daily and nightly period of work which corresponds to the higher and lower tariff. The aim of the paper was not to calculate input values into the model (which is the plan of another paper) but on the ground of input values (which can be measured if the reconstruction plant is in case) that can vary from case to case or as in this case for the presupposed plant to perform general calculation and on such values perform simulation.

For such a basic model an average cooling and heating load is shown in Fig. 8. On the basis of the average daily load the thermal load, during daytime and nigh time operations of the system, is determined corresponding to the operation of the system within a higher or lower tariff-rate. The value of thermal loads within the day period is obtained assuming that the load of the day period is $50 \%$ higher than the average daily value, while the value of the thermal loads for the night period corresponds to $30 \%$ of the average daily load.

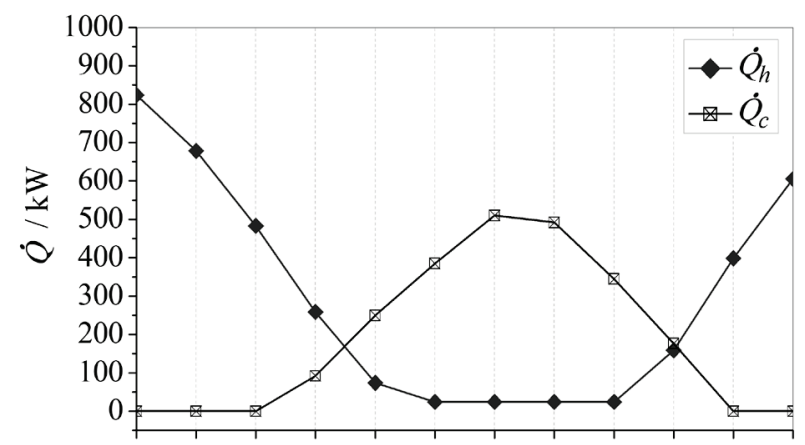

Jan Feb Mar Apr May June July Aug Sep Oct Nov Dec Month

Figure 8 Average cooling and thermal load of the basic model

Fig. 9 and Fig. 10 indicate the average load of the CCHP system in the strategy of following the thermal load and the minimum allowed ratio of the electric load of $50 \%$, during periods of higher and lower tariff.

The results of the simulation of the operation of the CCHP system, which indicate the integrated values of energy flows, in a one year period, are shown in Fig. 11.

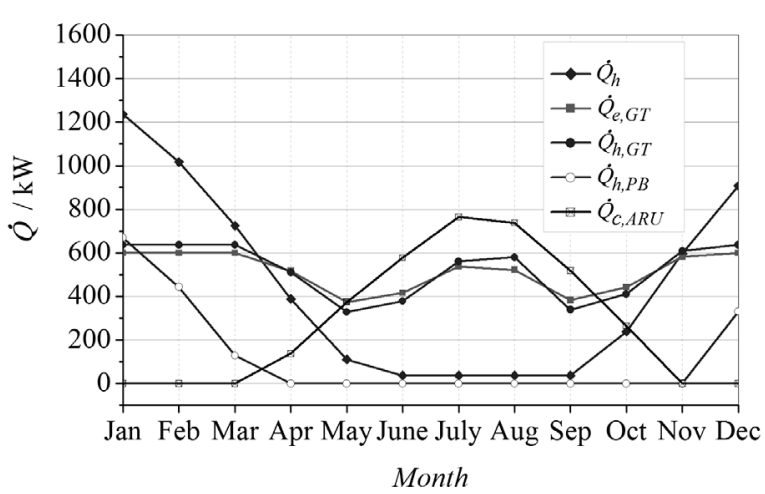

Figure 9 The load of the CCHP system during a higher tariff period and the limitation $X_{e, \min }=50 \%$

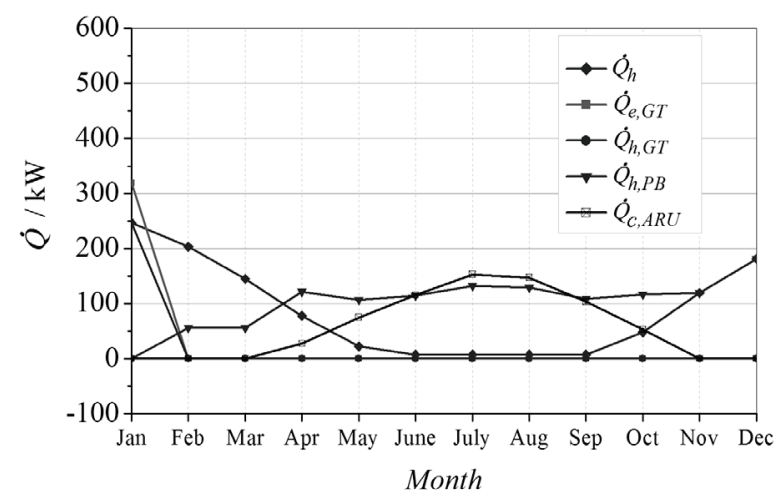

Figure 10 The load of the CCHP system during a lower tariff period and the limitation $X_{e, \min }=50 \%$

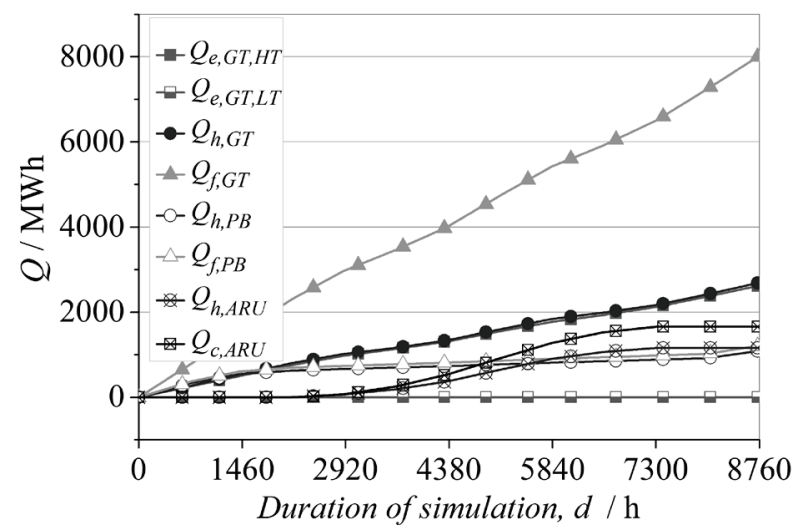

Figure 11 The energy of the CCHP system during the higher and lower tariff and the limitation $X_{e, \min }=50 \%$

For the economic and sensitivity analysis, the prices shown in Tab. 1 were used.

Table 1 Energy cost rate included in calculations [12 $\div 15]$

\begin{tabular}{|l|c|c|c|}
\hline Energy type & Mark & Unit & Price \\
\hline Natural gas & $C_{f, N G}$ & $€ / \mathrm{GJ}$ & 12,296 \\
\hline Heating oil & $C_{f, H O}$ & $€ / 1$ & 0,4915 \\
\hline Electric energy (HT) & $C_{e, H T}$ & $€ /(\mathrm{kW} \cdot \mathrm{h})$ & 0,1381 \\
\hline Electric energy (LT) & $C_{e, L T}$ & $€ /(\mathrm{kW} \cdot \mathrm{h})$ & 0,0740 \\
\hline
\end{tabular}

\section{Sensitivity analysis}

The changing values of the input techno-economic parameters affect the value of output variables such as the efficiency and the return rate of investment. Considering that the decision on the investment in the project is made on the basis of these values, an analysis of sensitivity [34] 
is made in order to be able to predict the behaviour of the system in relation to changing conditions.

The purpose of the sensitivity analysis is to show the sensitivity of the simulation model based on the changes in the input data or to investigate how a particular project's techno-economic parameters react to changes of certain parameters. The method is based on the "freezing" of all variables in the model, except one, on the basis of which its effect on the output is being determined. The paper presents an analysis of sensitivity based on simulations of CCHP model developed in the programming language Modelica and simulation environment SimulationX. The analysis of the influence of the following techno-economic parameters:

- the selling price of electrical energy $C_{e, s}$,

- the purchase price of electrical energy $C_{e, p}$,

- the price of natural gas $C_{f, N G}$,

- the price of fuel heating oil $C_{f, H O}$,

- the total investment expanse $E_{t o t}$,

- the minimal ratio of the electric load $X_{e, \text { min }}$,

- the coefficient of performance $C O P_{C R U}$,

- the boiler efficiency $\eta_{B}$.

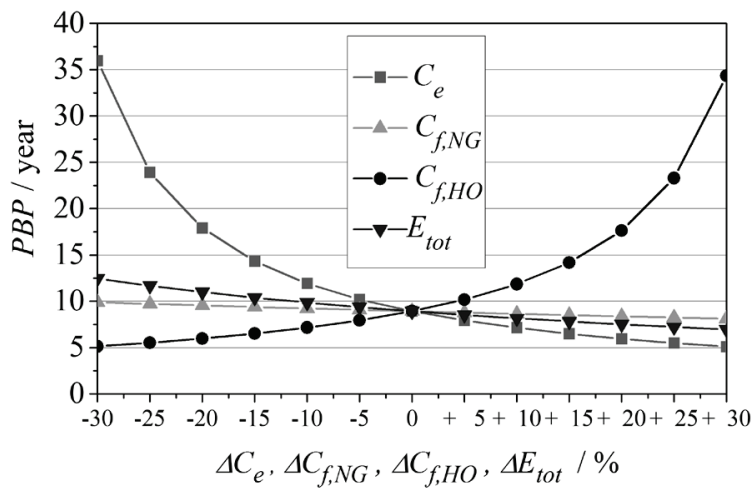

Figure 12 Payback period of the CCHP model depending on the changes in energy and investment prices

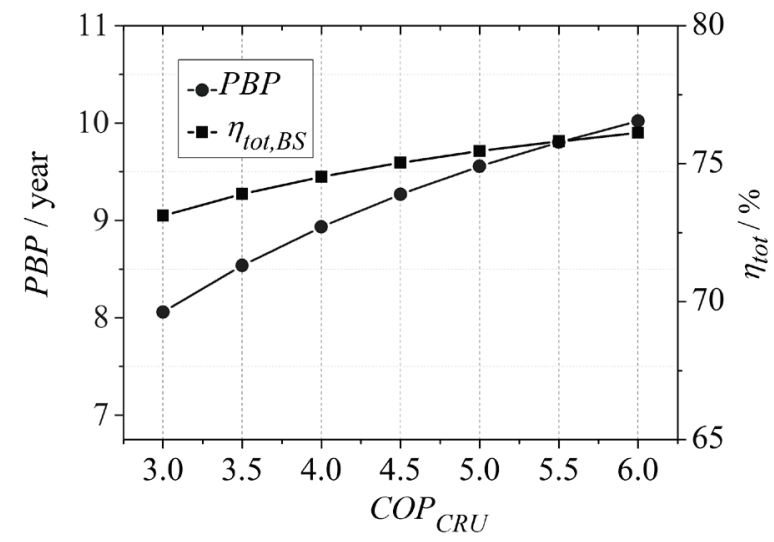

Figure $13 P B P$ and $\eta_{t o t, B S}$ of the CCHP model depending on changes of the $C O P_{C R U}$ of the basic model

Simulation is performed for the starting parameter values $C O P_{C R U}=3, \eta_{B}=0,8, \eta_{e, a}=0,35$ in case that all electric energy is purchased from the coal power plant. Fig. 12 indicates the results of the simulation of the CCHP model for $P B P$ during the period of one year, for changing range of influential parameters within the limits of $\pm 30 \%$. From the results it is visible that the most influential parameter on $P B P$ is the selling price of electrical energy $C_{e, s}$, as well as the price of natural gas $C_{f, N G}$.

Fig. 13 and Fig. 14 indicate changes in technoeconomic parameters of the CCHP model depending on the change of the coefficient of performance and the boiler efficiency of the basic model. The results indicate a relatively low impact on the $P B P$, but a significant impact on the total efficiency of the basic system model. From the technical point of view this result raises the question of feasibility about the investing into a CCHP system.

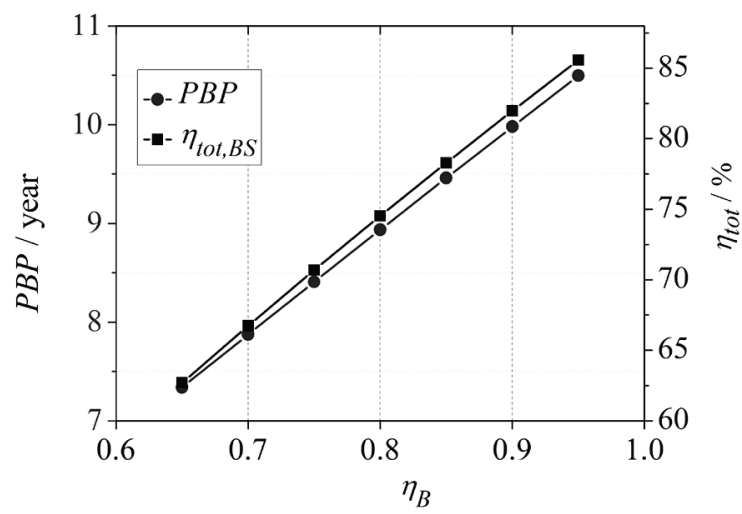

Figure $14 P B P$ and $\eta_{t o t, B S}$ of the CCHP model depending on changes of $\eta_{B}$ of the basic model

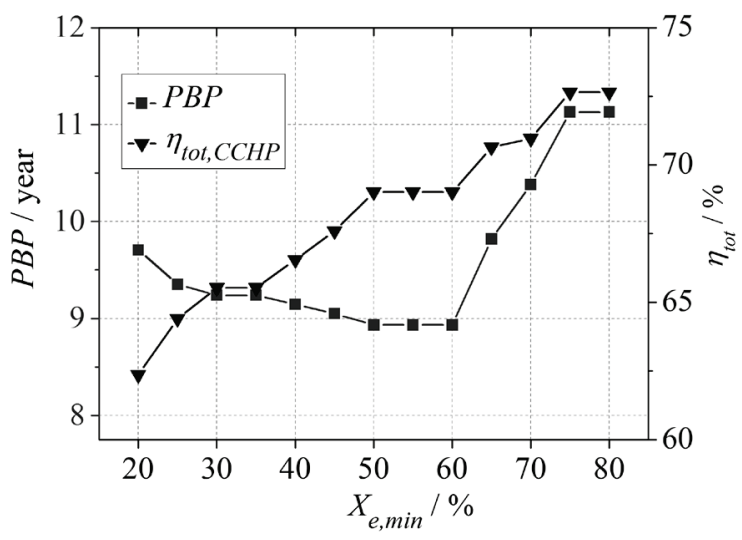

Figure 15 The sensitivity of the techno-economic parameters $P B P$ and $\eta_{t o t, B S}$ of the CCHP model to the minimum electrical load ratio $X_{e, \text { min }}$

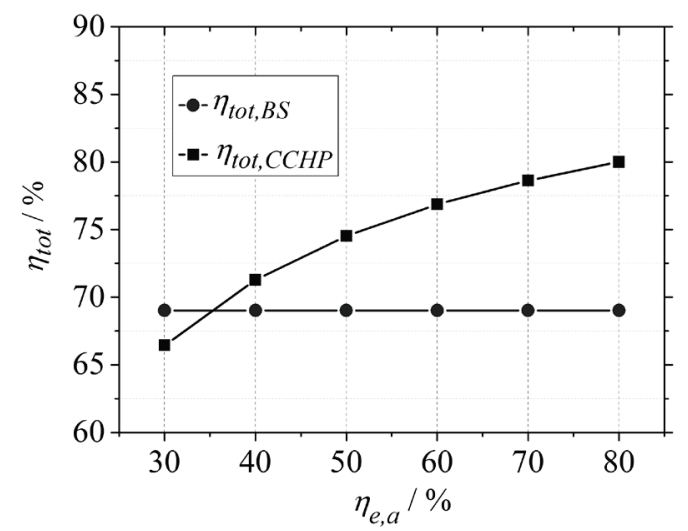

Figure 16 The total level of efficiency in relation to the change in the average efficiency generation of electricity $\eta_{e, a}$

Fig. 15 indicates changes in techno-economic parameters of the CCHP model depending on the minimum value $X_{e, \min }$. The results show that the optimum value is in the range of $X_{e \text {, min }}$ between $50 \div 60 \%$. 
For the $X_{e, \text { min }}$ lower than $50 \%$ an increase in the operating hours of the gas turbine occurs during the period of unfavourable low tariffs, which affects the increase of the value of $P B P$.

For the value of $X_{e \text {,min }}$ greater than $60 \%$, an increase in $\eta_{t o t, C C H P}$ due to the reduced number of operating hours of the gas turbine, and an increase in the portion of heat produced by the peak boiler, operating with a higher $\eta_{B}$ than $\eta_{t o t, G T}$, affecting thus operating the increase in the total level of energy efficiency of the CCHP model, $\eta_{\text {tot, } C \text { CHP. }}$

Fig. 16 indicates the total energy efficiency in relation to changes of the average efficiency of the power production system $\eta_{e, a}$, where the average efficiency is the ratio between the gross production of electrical energy and the consumption of primary energy for its production, and it is calculated as the average value for the entire European Union based on the Eurostat data. The values $\eta_{e, a}$ depend on the production and type of fuel.

\section{Conclusion}

The system of separate production, which includes the production of thermal energy from a boiler and cooling energy from the compression refrigeration unit powered by electrical energy from the external network, can be replaced by a CCHP system based on the work of micro-turbine and the absorption refrigeration unit.

Using the programming language Modelica, for the modelling complex physical systems, a software solution was created as well as a dynamic simulation. Modelica programme language allows the development of individual models of certain components depending on needs. Commercial applications do not offer the possibility to influence on the programme code and so constrains the user to develop individual model components.

The simulation of a low power CCHP system was conducted using a micro-turbine and a two-stage absorption refrigeration unit. An analysis and comparison of CCHP system in relation to the model of separate production of heating and cooling energy was also conducted. The simulation was conducted assuming that the basic model uses oil for the operation of the boiler, while the CCHP system uses natural gas for the microturbines and the peak boiler.

A simulation of the system for changing technoeconomic conditions was also conducted. The results indicate that the operation of CCHP system during periods of lower and higher tariffs, following the strategy of the thermal load, is economically justified. The minimum load ratio of $50 \%$ allows the system to operate with a lower tariff, while the energy needed for the thermal loads is being compensated from the peak boiler powered by natural gas, preventing thus the operation of micro-turbines at low loads, and reducing in turn the amount of electricity produced during the unfavourable tariff.

A sensitivity analysis was also conducted in relation to the change of parameters such as the COP compressioncooling unit, the efficiency of the boiler in the basic model of separate production, and the load ratio of the micro-turbines.
The simulation results indicate that, regardless of the fact that the basic model (BS) could be improved from a technical standpoint, such a system permanently increases the costs in relation to the CCHP system which can generate profit, depending on the economic parameters such as fuel and electrical energy costs.

Model produced using Modelica/SimulationX is capable for dynamic simulations, using adequate input parameters and dynamic boundary conditions. Further research will be aimed to dynamic simulations on selected examples and comparison with results achieved using Transys in order to evaluate adequacy of Modelica for such analyses.

\section{References}

[1] Soares, C. Microturbines. Elsevier Inc, Elsevier / Butterworth-Heinemann, Amsterdam, 2007.

[2] Moore, M. J. Micro-turbine Generators. The Cromwell Press, 2002.

[3] Bruno, J. C.; Valero, A.; Coronas, A. Performance analysis of combined microgas turbines and gas fired water $/ \mathrm{LiBr}$ absorption chillers with post-combustion. // Applied Thermal Engineering. 25, (2005), pp. 87-99. DOI: 10.1016/j.applthermaleng.2004.05.002

[4] Huicocheaa, A.; Rivera, W.; Gutiérrez-Uruetaa G.; Bruno J. C.; Coronas A. Thermodynamic analysis of a trigeneration system consisting of a micro gas turbine and a double effect absorption chiller. // Applied Thermal Engineering. 31, (2011), pp. 3347-3353. DOl: 10.1016/j.applthermaleng.2011.06.016

[5] Ameri, M.; Hejazi, S. H. The study of capacity. Enhancement of the Chabahar gas turbine installation using an absorption chiller. // Applied Thermal Engineering. 24, (2004), pp. 59-68. DOI: 10.1016/S1359-4311(03)00239-4

[6] Liu, M.; Shi, Y.; Fang F. Combined cooling, heating and power systems. // A survey, Renewable and Sustainable Energy Reviews. 35, (2014), pp. 1-22. DOI: 10.1016/j.rser.2014.03.054

[7] Xu, D.; Qu, M. Energy, environmental, and economic evaluation of a CCHP system for a data center based on operational data. // Energy and Buildings. 67, (2013), pp. 176-186. DOI: 10.1016/j.enbuild.2013.08.021

[8] Lozano, M. A.; Ramos, J. C.; Serra, L. M. Cost optimization of the design of CHCP (combined heat, cooling and power) systems under legal constraints. // Energy. 35, (2010), pp. 794-805. DOl: 10.1016/j.energy.2009.08.022

[9] Wu, J.; Wang, J.; Li, S. Multi-objective optimal operation strategy study of micro-CCHP system. // Energy. 48, (2012), pp. 472-483. DOI: 10.1016/j.energy.2012.10.013

[10] Jayasekara, S.; Halgamuge, S. K.; Rahula Attalage, R. A.; Rajarathne, R. Optimum sizing and tracking of combined cooling heating and power systems for bulk energy consumers. // Applied Energy. 118, (2014), pp. 124-134. DOI: 10.1016/j.apenergy.2013.12.040

[11] Glavan, I.; Prelec, Z.; Pavkovic, B. Modelling, Simulation and Optimization of Small-Scale CCHP Energy Systems. // International Journal of Simulation Modelling. 14, 4(2015), pp. 683-696. DOI: 10.2507/IJSIMM14(4)10.336

[12] The tariff system for electric energy produced from renewable sources and cogeneration (in Croatian), NN 63, (2012).

[13] HROTE Croatian Energy Market Operator. URL: http://www.hrote.hr/default.aspx?id=38. (04.04.2015).

[14] European Commission - Energy. http://ec.europa.eu/energy/. (04.04.2015). 
[15] European Commission - Weekly oil bulletin. URL: http://ec.europa.eu/energy/en/statistis/weekly-oil-bulletin/ (04.04.2015).

[16] EUR-Lex. Directive 2004/8/EC of the European Parliament and of the Council of 11 February 2004 on the promotion of cogeneration based on a useful heat demand in the internal energy market and amending Directive 92/42/EEC (2004). http://eur-lex.europa.eu/legalcontent/EN/ALL/?uri=CELEX:32004L0008. (05.01.2015).

[17] Modelica. http://www.modelica.com.(05.03.2015).

[18] Tille, M. Introduction to physical modelling with Modelica. Kluwer Academic Publishers, 2001.

[19] Fritzon, P. Introduction to Modeling and Simulation of Technical and Physical System with Modelica. Wiley-IEEE Press, 2011.

[20] SimulationX. https://www.simulationx.com. (05.03.2015).

[21] Kolanowski, B. F. Guide to Microturbines. Fairmont Press, 2004.

[22] Ingersoll Rand. http://company.ingersollrand.com. (02.04.2015).

[23] Capstone Turbine Corporation. http://www.capstoneturbine.com (02.04.2015).

[24] Basrawi, F.; Yamada, T; Nakanishi, K.; Naing S. Effect of ambient temperature on the performance of micro gas turbine with cogeneration system in cold region. // Applied Thermal Engineering. 31, (2011), pp. 1058-1067. DOl: 10.1016/j.applthermaleng.2010.10.033

[25] Broad. http://www.broad.com_(02.04.2015).

[26] Glavan, I.; Prelec, Z. The analysis of trigeneration energy system and selection based of the best option based on criteria of GHG emission cost and efficiency. // Engineering Review. 32, 3(2012), pp. 131-139.

[27] Cleaver-Brooks. http://www.cleaver-brooks.com. (02.04.2015).

[28] Wolfram Research, Current \& Historical Weather Dana. http://www.wolfram.com. (12.01.2015).

[29] Chin, L.; Spatz, M. W. Issues Relating to the Adoption of R-410A in Air Conditioning Systems. // $20^{\text {th }}$ International Congress of Refrigeration, IIR/IIF, 1999, Sidney.

[30] Darrow, K.; Tidball, R.; Wang, J.; Hampson, A. (2015). Catalog of CHP technologies, ICF Int., funding: U.S. Environmental Protection Agency, Combined Heat and Power Partnership, U. S. Dept. of Energy

[31] Regulation on unit charges, corrective coefficients, criterions and standards for determining the charge for emissions of carbon dioxide into the environment (in Croatian), NN 48-1069

[32] RETScreen International. http://www.retscreen.net. (05.03.2015).

[33] TRANSYS.http://sel.me.wisc.edu/trnsys/index.html. (05.03.2015).

[34] Saltelli, A. Sensitivity Analysis in Practice: A Guide to Assessing Scientific Models. John Wiley \& Sons, 2004.

\section{Authors' addresses}

Ivica Glavan, PhD

Maritime department, University of Zadar dr. Mihovila Pavlinovića 1, HR-23000 Zadar, Croatia

E-mail: ivica.glavan@unizd.hr

Zmagoslav Prelec, Prof. PhD

Department of Thermodynamic and Energy Engineering, Faculty of Engineering, University of Rijeka Vukovarska 58, HR-51000 Rijeka, Croatia

E-mail: zprelec@riteh.hr

\section{Branimir Pavković, Prof. PhD}

Department of Thermodynamic and Energy Engineering, Faculty of Engineering, University of Rijeka Vukovarska 58, HR-51000 Rijeka, Croatia

E-mail: branimir.pavkovic@riteh.hr 